\title{
Effect of leachate loading rate and incubation period on the treatment efficiency by $T$. versicolor immobilized on foam cubes
}

\author{
J. Saetang; *S. Babel \\ Sirindhorn International Institute of Technology, Thammasat University, Rangsit Campus, \\ Pathumthani, Thailand \\ Received 18 January 2009; $\quad$ revised 27 March 2009; accepted 15 May 2009; available online 1 June 2009
}

\begin{abstract}
This study focuses on treatment of landfill leachate in column experiments by immobilized Trametes versicolor on polyurethane foam, collected from Nonthaburi landfill site, Thailand. In this study, glucose was used as a co-substrate. The effect of biomass growth on color removal was observed by immobilizing fungi on polyurethane foam. The same immobilized fungi were used for four cycles of 5 days each to find the reuse of fungi. Leachate was diluted to see the effect of organic loading on color removal. At optimum $\mathrm{pH}$ of 4 and in 20 days with $3 \mathrm{~g} / \mathrm{L}$ of glucose, the fungi could decolorize $78 \%$ and $63 \%$ for 5 -times dilution and concentrated leachate, respectively, using immobilized fungi after 4 days initial growth. Fungi could also reduce biological oxygen demand and chemical oxygen demand of $52 \%$ and $42 \%$ (with initial biological oxygen demand and chemical oxygen demand of 48,900 and 96,512 mg/L), respectively, with glucose $3 \mathrm{~g} / \mathrm{L}$ in concentrate leachate and with 4 days initial immobilization of fungi on polyurethane foam. About 1-6\% higher color removal was observed on day 20 with 15 days fungi immobilization initially as compared to 4 days immobilization. Higher removal efficiency was observed for the same leachate after dilution due to reduction in organic loading. Addition of co-substrate enhances significantly removal of color, biological oxygen demand and chemical oxygen demand. Chemical oxygen demand removal reached to $0.6 \mathrm{mg} / \mathrm{mg}$ of biomass with the co-substrate. Therefore, white rot fungi can be considered as potentially useful microorganisms in landfill leachate treatment.
\end{abstract}

Keywords: Biodegradation; Decolorization: Landfill leachate; Organic loading; White rot fungi

\section{INTRODUCTION}

Recent estimates indicate that annual generation of municipal solid waste in the USA is projected to increase to 253 million tons in 2010 (USEPA, 2007). In Thailand, more than 14.3 million tons/y or 39,200 tons/day of solid waste is produced in urban areas all over the country, with an annual increasing rate of about $3 \%$ (PCD, 2005). Currently, a majority of wastes (about $65 \%$ ) are being disposed in open dumps, whereas the remainder is being managed by sanitary landfill (3\%). Most sanitary landfills in Thailand employ stabilization ponds as the main treatment method for leachate. Under tropical climatic conditions, heavy rainfall during monsoon season yields huge amounts of leachate to be treated, whereas the capacity of the existing treatment system is usually limited. Inadequately treated water is then discharged into the nearby water body, causing severe pollution problems (Chiemchaisri and Srisukphun, 2003). Nonthaburi landfill site (location used in this study) has

*Corresponding Author Email: sandhya@siit.tu.ac.th Tel.: +66 2986 9009; Fax: +66 29869112 a total area about $0.194 \mathrm{~km}^{2}$ and receives more than 900 tons/day of municipal solid wastes from Nonthaburi Province, Thailand (as of 2007). The site has been in operation since 1982 and at present the total accumulated dumped waste is more than one million cubic meters. Each cell is about $0.0384 \mathrm{~km}^{2}$ and is normally filled up in one year.

Even though some physical and chemical methods are effective for the removal of high strength organic and inorganic materials, the high cost per unit volume is the major draw back (Amaral et al., 2004; Erkurt et al., 2007; Kandelbauer and Guebitz, 2005).

The utilization of biodegradative abilities of some white rot fungi seems to be promising. Researchers are now focusing on white rot fungi for use in bioremediation processes since these organisms have the ability to degrade a wide range of environmental pollutions (Fu and Viraraghavan, 2001; Paszczynski and Crawford, 1995; Pointing, 2001; Shah and Nerud, 2002). The decolorization can be achieved either by adsorption or 
oxidative degradation by the enzymes ( $\mathrm{Fu}$ and Viraraghavan, 2001; Knapp et al., 1999). While many studies have been carried out on biodecolorization, for example, decolorization of textile dyes and their effluents using white rot fungi (Sathiya et al., 2007); biological treatment of a pulp and paper industry effluent by Fomes lividus and Trametes versicolor (Selvam et al., 2002); degradation of lignin in pulp mill wastewaters by white rot fungi on biofilm (Wu et al., 2005), no attention has been paid to the treatment of leachate by white rot fungi. Thus, this study was undertaken and it focuses on landfill leachate treatment using Trametes versicolor BCC 8725 because of the previously shown potential for decolorization and organic treatment (Benito et al., 1997; Mehna et al., 1995, Nilsson et al., 2006).This study investigates treatment of leachate as discharged from landfill to the stabilization pond using immobilized white rot fungi, namely Trametes versicolor BCC 8725 with and without use of co-substrate in column experiments. The effect of biomass growth on color removal by immobilizing fungi on polyurethane foam (PUF) for 4 and 15 days and the effect of organic loading (by dilution), as well as the reuse of fungi in different cycles are also observed. This research was conducted in $2007-2008$ at the Environmental Technology Laboratory, Sirindhorn International Institute of Technology, Thammasat University.

\section{MATERIALS AND METHODS}

Fungi and leachate collection

T. versicolor BCC 8725 was obtained from BIOTECH Central Research Unit, Thammasat University, Pathumthani, Thailand. The fungi were grown in culture tubes containing Potato dextrose agar (PDA) at $25^{\circ} \mathrm{C}$ for 1 week. Leachate was collected from a pipe as discharged from landfill, which is about 8 months old, to the stabilization pond in March 2008 and then stored at $4{ }^{\circ} \mathrm{C}$ to avoid any decomposition.

\section{Sub-culture of fungi}

Potato dextrose agar was used as a culture media. The boiled agar was poured into culture tubes with caps. The tubes were then kept in autoclave at $121^{\circ} \mathrm{C}$ for 15 min and cooled until solidified. The fungi were spread over the PDA in the culture tube and kept in the incubator at $25{ }^{\circ} \mathrm{C}$ for 1 week. Sub-culture was done once a week to obtain active fungi.
Scanning electron microscope (SEM) image

For SEM imaging, the immobilization of T. versicolor BCC 8725 on PUF cubes was done with $2 \%(\mathrm{v} / \mathrm{v})$ glutaraldehyde in $0.1 \mathrm{M}$ phosphate buffer ( $\mathrm{pH} 7.2$ ) for 2 $\mathrm{h}$. The specimens were rinsed twice in phosphate buffer for $10 \mathrm{~min} /$ each and once in distilled water for $10 \mathrm{~min}$. The specimens were then dehydrated with a graded series of ethanol (10\%, $20 \%, 30 \%, 50 \%, 70 \%$ and $95 \%$ ) for 10 min each and absolute ethanol for 3 times (10 min/time) using critical point dryer, Balzers model CPD 020). The dry cubes were mounted and coated with gold using Sputter Coater, Balzers model SCD 040) and observed under a scanning electron microscope (JEOL, model JSM-6400).

\section{Leachate characterization before treatment}

The leachate was filtered to remove suspended solids before measurement and was analyzed for $\mathrm{pH}$, COD, $\mathrm{BOD}_{5}$, SS, $\mathrm{NH}_{3}-\mathrm{N}$ according to the SMEW (1998). The heavymetals such as $\mathrm{Ni}, \mathrm{Cr}, \mathrm{Cd}, \mathrm{Pb}$ and $\mathrm{Hg}$, were analyzed using the Inductively coupled plasma spectroscopy (ICP Optima 2100 DV). The color of the leachate was measured by ADMI Tristimulus filter method using Hewlett Packard spectrophotometer model 8452A Diode Array.

\section{Mycelial suspension and immobilization of fungi on} PUF

Mycelial suspension: Mycelial suspension was prepared by punching four pieces of fungi from the culture tube using the sterile loop in $100 \mathrm{~mL}$ of sterile potato dextrose broth (PDB). Flasks were plugged with cotton and were agitated for $24 \mathrm{~h}$ in a rotary shaker at $150 \mathrm{rpm}$.

Polyurethane foam sterilization: 80 pieces of PUF were first put into the $1,000 \mathrm{~mL}$ PDB in 2,000 mL flasks so that PUF is not too crowded. The flasks were plugged with cotton and then sterilized in autoclave for $15 \mathrm{~min}$ prior to use.

Fungi immobilization on PUF: To $1,000 \mathrm{~mL}$ of PDB containing 80 pieces of PUF, $100 \mathrm{~mL}$ of mycelial suspension was added in a 2,000 mL flask. The flasks were kept at ambient temperature $\left(30-33^{\circ} \mathrm{C}\right)$. The PUF were covered with fungal mycelium within 4 days and were used for the study. Some of the PUF were left in the PDB and the fungi were allowed to grow for 15 days and used for the study to see the effect of initial biomass growth on removal efficiency. Ten pieces of PUF with immobilized fungi were used for each varying condition. 
Biomass growth of immobilized T. versicolor BCC 8725 (continuous experiment)

After fungal immobilization, the dry weight (dried at $80^{\circ} \mathrm{C}$ for $48 \mathrm{~h}$ ) of one piece of PUF with immobilized fungi out of 800 pieces was measured after each cycle of 5 days as a representative and was compared with initial weight to find the biomass growth. Suspended fungal cells that were not attached were not counted. All processes were done under sterile condition at ambient air temperature $\left(30-33^{\circ} \mathrm{C}\right)$.

\section{Batch experiment}

Batch experiments were conducted to find out the optimum $\mathrm{pH}$, optimum dose for each co-substrate and the effect of contact time. Optimum conditions are defined as conditions where maximum color removal was achieved.

\section{Effect of pH on color removal}

Ten pieces of PUF with immobilized fungi were put in flasks containing $100 \mathrm{~mL}$ of leachate. The $\mathrm{pH}$ in each flask was varied using $1 \mathrm{~N} \mathrm{NaOH}$ and $1 \mathrm{~N} \mathrm{HCl}$ solution to pH 3, 4, 5 and one flask was used as a control. The flasks were plugged with cotton and covered with aluminum foil. All flasks were shaken at $150 \mathrm{rpm}$ for 1 to 5 days and color removal was observed. The $\mathrm{pH}$ was monitored on a daily basis and changes were recorded. All processes were done under sterile conditions at ambient temperature.

Effect of co-substrates concentration on color removal

Leachate $(100 \mathrm{~mL})$ was adjusted to the optimum $\mathrm{pH}$ and 10 pieces of PUF with immobilized fungi were then added. Concentration of co-substrate (glucose, cassava and corn starch) was varied at 1, 2, $3 \mathrm{~g} / \mathrm{L}$. In one flask, no co-substrate was added (control). All flasks were shaken at $150 \mathrm{rpm}$ for 15 days to find the effect of contact time. The leachate was filtered and color removal was monitored. However, the results of batch experiment are not shown except at the optimum conditions which were used in continuous experiment.

\section{Continuous experiment}

Continuous experiments were conducted to evaluate a flow-through system as such system is practically used in real operation. Glucose $3 \mathrm{~g} / \mathrm{L}$ as co-substrate at $\mathrm{pH} 4$ gave the maximum color removal in batch experiments and the same condition was used in continuous experiments.
The reactor was constructed with acrylic sheets with the inner dimension of $5 \mathrm{~cm}$ width, $28.7 \mathrm{~cm}$ length and 35 $\mathrm{cm}$ height. Three baffles were placed as partitions in each reactor to have an up-down flow as shown in Fig. 1 in order to increase the contact time. Each baffle was $2.9 \mathrm{~mm}$ thick and baffles were put close to the bottom to allow only the liquid (not the PUF immobilized fungi) to pass through. The water level was maintained $5 \mathrm{~cm}$ below the top so the liquid volume is $3 \mathrm{~L}$. A small hole was made on the top for PUF sampling to measure the biomass growth of fungi. Air diffusers were put at the bottom of each compartment to provide sufficient air. The reactor was packed with immobilized fungi attached on PUF (200 pieces) in each compartment (total 800 PUF).

To study the effect of organic loading on decolorization efficiency, experiments were conducted with 5 times diluted leachate and concentrated leachate. The influent (raw leachate) with an additional carbon source (glucose $3 \mathrm{~g} / \mathrm{L}$ for concentrated leachate and 600 $\mathrm{mg} / \mathrm{L}$ for 5 times diluted leachate) and adjusted $\mathrm{pH}$ ( $\mathrm{pH}$ 4) was fed continuously from the top of the reactor and flowed down and up in a zigzag direction (Fig. 1) until the effluent came out from the bioreactor. This flow pattern provided sufficient contact time for reaction. The incoming flow rate of leachate was adjusted to 0.4 $\mathrm{mL} / \mathrm{min}$ so that the retention time was 5 days. Treated leachate was continuously recycled (at the rate of 0.4 $\mathrm{mL} / \mathrm{min})$ and the remaining was an effluent $(0.4 \mathrm{~mL} / \mathrm{min})$ while retaining the fungus. According to Fig. 1, the influent flow is $0.4 \mathrm{~mL} / \mathrm{min}$ and effluent flow is equal to influent flow. Although the recycle leachate is 0.4 $\mathrm{mL} / \mathrm{min}$, the influent flow to reactor after one cycle is 0.8 $\mathrm{mL} / \mathrm{min}$. In this condition, the influent flow would increase and the contact time will decrease, but the influent loading is reduced as the leachate gets diluted due to recycling of treated leachate. Throughout the experiment, treated leachate was analyzed at the outlet of the bioreactor for color, BOD and COD reduction. The experiment was performed at ambient temperature (30$33^{\circ} \mathrm{C}$ ) and continued until removal efficiency became almost stable. Each cycle was run for 5 days. New leachate was introduced in the next cycles using the same immobilized fungi to study the efficiency of reuse of fungi in consecutive cycles.

\section{Determination of leachate characteristics after treatment}

Removal of color, BOD, COD and heavy metals were investigated after fungal treatment and the results were compared with the initial value. 


\section{RESULTS AND DISCUSSION}

The characteristics of landfill leachate compared with industrial effluent standards in Thailand are shown in Table 1. It can be seen from Table 1 that most of the parameters well exceed the standards. The leachate was dark-black and acidic with extremely high suspended solids. The BOD and COD values were very high, however, the ammonia concentration was very low indicating the leachate was very fresh. The heavy metal concentrations were under the standard levels, except for $\mathrm{Cd}$ and $\mathrm{Hg}$. However, experiments were conducted with filtered leachate to remove suspended solids so that the biomass growth on PUF could occur efficiently. It was observed that BOD and COD were reduced to some extent due to a high amount of suspended solids by filtration. The BOD and COD after filtration are 46,060 and 75,510 mg/L, respectively. The BOD and COD after 5 times dilution are 9,700 and 18,992 mg/L, respectively.

\section{Scanning electron microscope}

The mycelia immobilized PUF cubes SEM images are shown in Figs. 2a and 2b.

Fig. 2a shows the spore-producing structure of $T$. versicolor BCC 8725 . Fig. 2b shows T.versicolor BCC 8725 immobilized on PUF. Immobilized fungi was used in this study as this will give higher biomass yield compared to mobilized fungi, since PUF cubes allow the contact area between cells and oxygen to be increased without the effect of shear stress. The increase in surface area of fungal biomass of PUF cubes tends to reduce the mass transfer limitations compared to free mycelia, which increases easy access to the

Table 1: Landfill leachate characteristic

\begin{tabular}{|c|c|c|c|}
\hline Parameters & Unit & Industrial effluent standard (PCD, 2006) & Value \\
\hline $\mathrm{pH}$ & - & $5.5-9.0$ & 5.7 \\
\hline Suspended solids (SS) & $\mathrm{mg} / \mathrm{L}$ & $<50$ (not exceed 150) & 16,584 \\
\hline Color & ADMI & No standard & 2,989 \\
\hline Biochemical oxygen demand $\left(\mathrm{BOD}_{5}\right)$ & $\mathrm{mg} / \mathrm{L}$ & $<20($ not exceed 60$)$ & 48,900 \\
\hline Chemical oxygen demand (COD) & $\mathrm{mg} / \mathrm{L}$ & $<120($ not exceed 400$)$ & 96,512 \\
\hline Ammonia & $\mathrm{mg} / \mathrm{L}$ & TKN <100 (not exceed 200) & 20 \\
\hline \multicolumn{4}{|l|}{ Total heavy metal concentration } \\
\hline$-\mathrm{Cd}$ & $\mathrm{mg} / \mathrm{L}$ & $<0.03$ & 0.05 \\
\hline - Cr (Total) & $\mathrm{mg} / \mathrm{L}$ & $<0.25$ & 0.17 \\
\hline$-\mathrm{Pb}$ & $\mathrm{mg} / \mathrm{L}$ & $<0.2$ & 0.02 \\
\hline - $\mathrm{Hg}$ & $\mathrm{mg} / \mathrm{L}$ & $<0.005$ & 0.02 \\
\hline$-\mathrm{Ni}$ & $\mathrm{mg} / \mathrm{L}$ & $<1.0$ & 0.1 \\
\hline
\end{tabular}

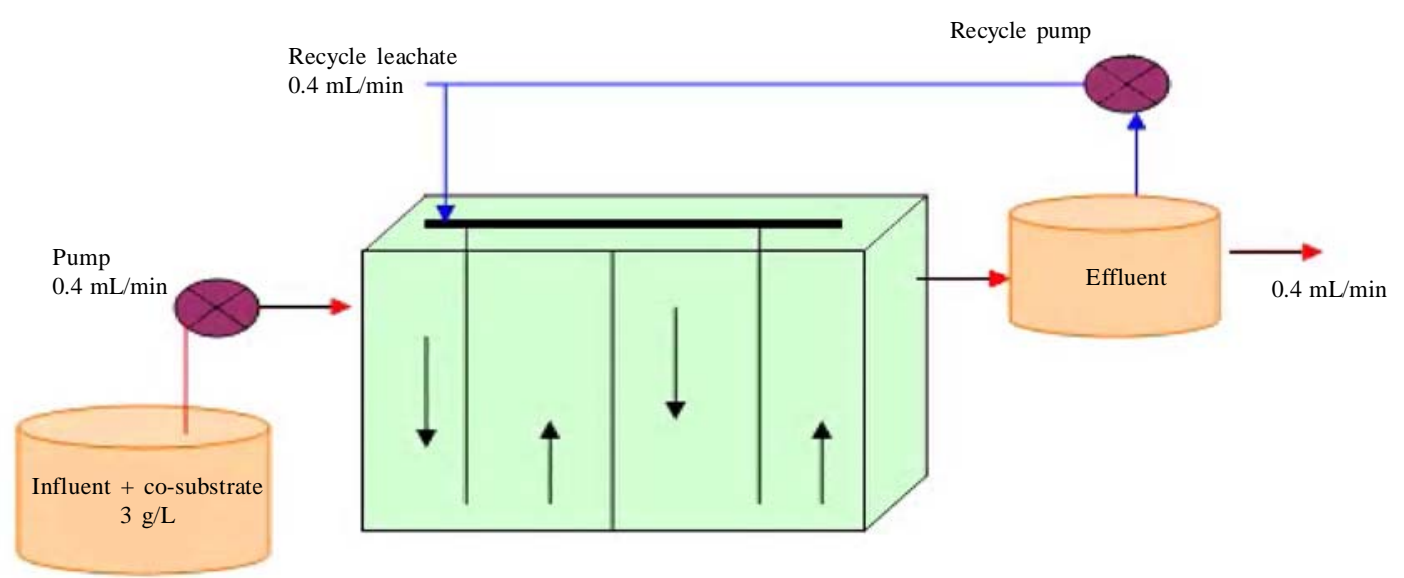

Fig.1: Continuous Bioreactor with leachate recirculation 
substrate utilization. In addition, oxygen is necessary for the production of ligninolytic enzymes by white rot fungi. It has been reported that immobilization of fungal cells using PUF could stably maintain the production of various enzymes at levels higher than achieved with suspended or pellets forms (Kim et al., 1999; Lapadatescu et al., 1997; Nakamura et al., 1999). Removal efficiency in this study was also found higher in the case of immobilized fungi compared to pellet form or mobilized fungi (results not shown).

\section{Effect of organic loading, co-substrate and degree of immobilization on removal efficiency}

Organic loading rate is one of the factors influencing the removal efficiency. The organic loading rates of concentrated and 5 times diluted leachate without glucose were 6.52 and $1.3 \mathrm{~g} \mathrm{BOD/L/d,} \mathrm{respectively.}$ Organic loading rate per unit surface area of PUF of concentrated leachate without glucose was 24.45 $\mathrm{mgBOD} / \mathrm{cm}^{2} / \mathrm{L} / \mathrm{d}$. As the treatment by T.versicolor BCC 8725 is dependent on $\mathrm{pH}$, the $\mathrm{pH}$ of leachate was adjusted to 4 which was found to be optimum during the batch experiments. The optimum dose of glucose as observed from the batch experiments, $3 \mathrm{~g} / \mathrm{L}$, was used as co-substrate.

Fig. 3 show the importance of co-substrate (with and without glucose addition) and the effect of organic loading (concentrated and 5 times diluted leachate) on the biomass growth, as well as the degree of immobilization. It was assumed that biomass growth on PUF was uniform. Based on this, Fig. 3 a, b and c shows the biomass growth at each cycle after 4 days initial immobilization in PDB and Figs. $3 \mathrm{~d}$ and e shows biomass growth at each cycle with 15 days initial immobilization on PUF. The biomass growth generally

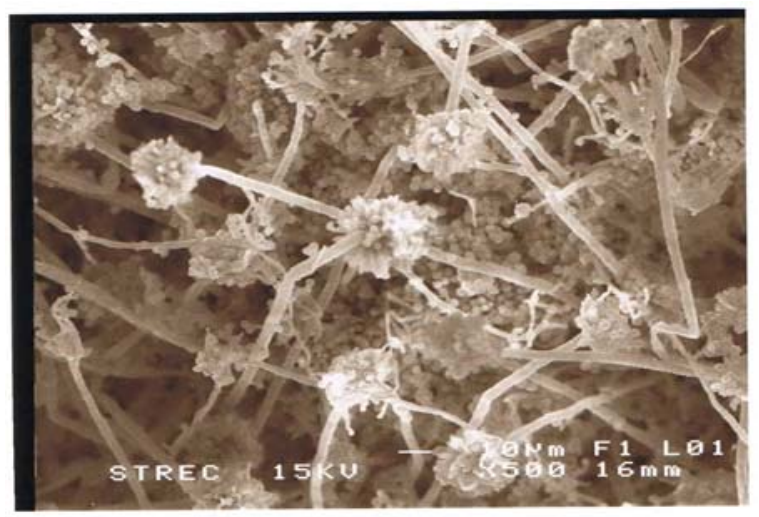

Fig. 2a: Spore-producing structure of T.versicolor BCC 8725 increases with the time, especially between cycle 1 and 2 and after that a slower increase was observed. About $15 \mathrm{mg}$ higher biomass growth per PUF was observed in 5 time diluted leachate than in concentrated leachate at the last cycle. The highest biomass growth (80.2 $\mathrm{mg} / \mathrm{PUF}$ ) was observed in 5 time diluted leachate using glucose as co-substrate with 15 days immobilization of fungi, while the lowest growth was in concentrated leachate without glucose with 4 days immobilization.

It is also observed that the percent removal increases with the number of cycles as the fungi get acclimatized to the leachate and more biomass growth occurs. When glucose was added, the biomass growth was high (almost double) which also resulted in higher color, BOD and COD removal. The fungi utilized glucose as food and gave better removal efficiency as compared to samples without glucose addition. The biomass growth coincided with the color, BOD and COD removal. About $32 \%$ higher decolorization was observed when glucose ( $3 \mathrm{~g} / \mathrm{L}$ ) was added in the concentrated leachate. From Fig. 3d, it can be seen that even though the initial biomass growth was high due to 15 days immobilization, still not much removal was observed because no co-substrate was added. Also, the amount of biomass did not increase much in the four cycles. However, it can be seen that removal increases when glucose is added (also Fig. 3a and b) which also enhances biomass growth. These results show that co-substrate plays an important role and is required for degradation of pollutants when using white rot fungi as well as for biomass growth.

It is known that carbon triggers ligninolytic activity in white rot fungi and is required for pollutant degradation and decolorization (Boominathan and Reddy, 1992; Knapp et al., 1997; Martin and Manzanares, 1994; Reddy, 1995). White rot fungi requires a carbon

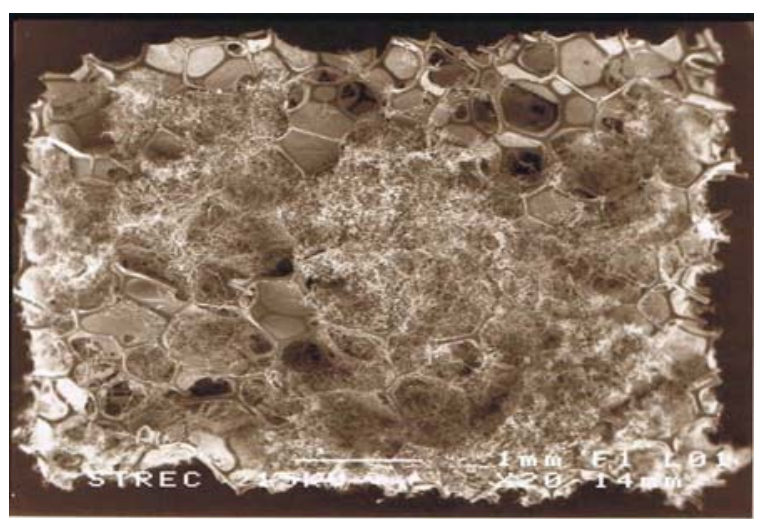

Fig. 2b: T.versicolor BCC 8725 immobilized on PUF 


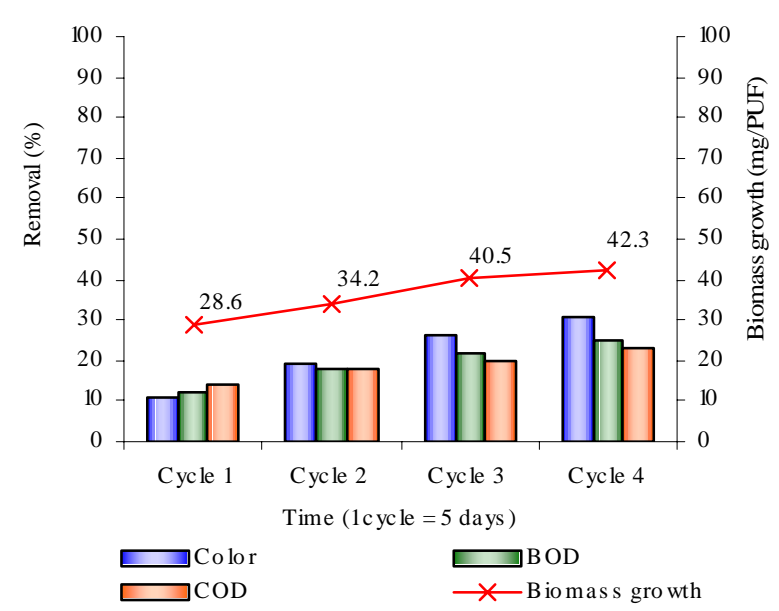

Fig. 3a: Percent removal and respective biomass growth in different cycles using concentrated leachate without glucose (4-day immobilization)

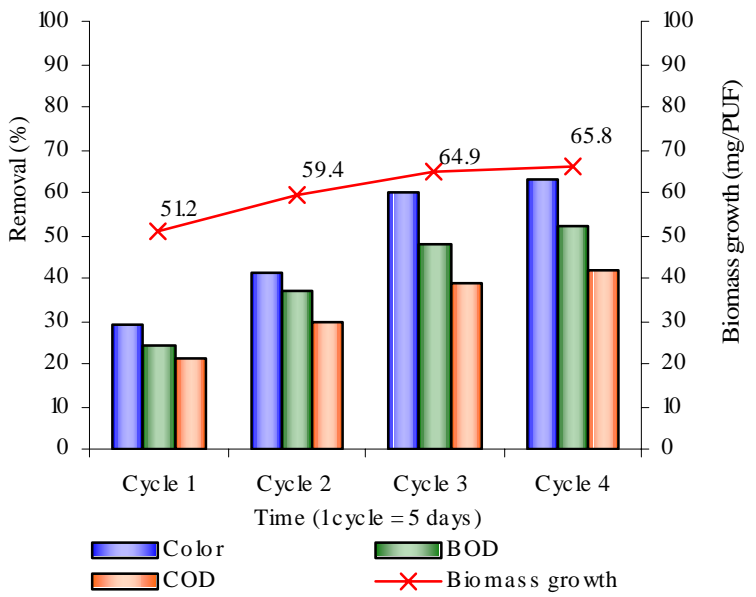

Fig. 3b: Percent removal and respective biomass growth in different cycles using concentrated leachate with glucose (4-day immobilization)

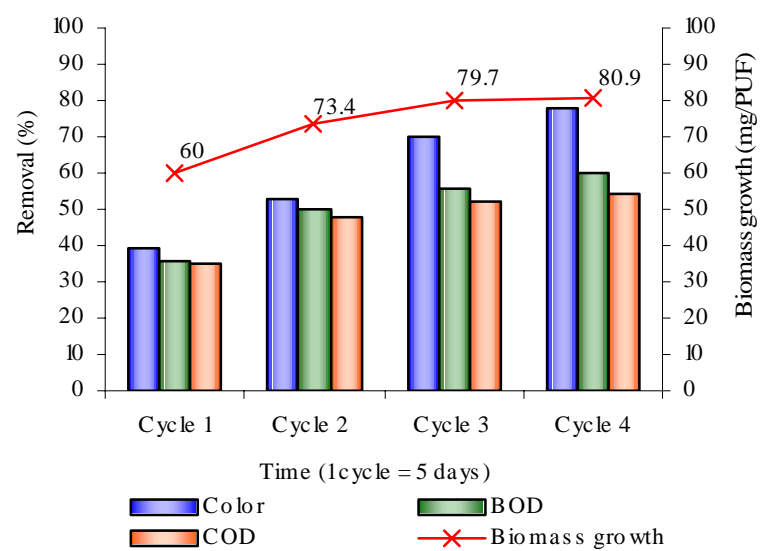

Fig. 3c: Percent removal and respective biomass growth in different cycles using 5-times diluted leachate with glucose (4-day immobilization)

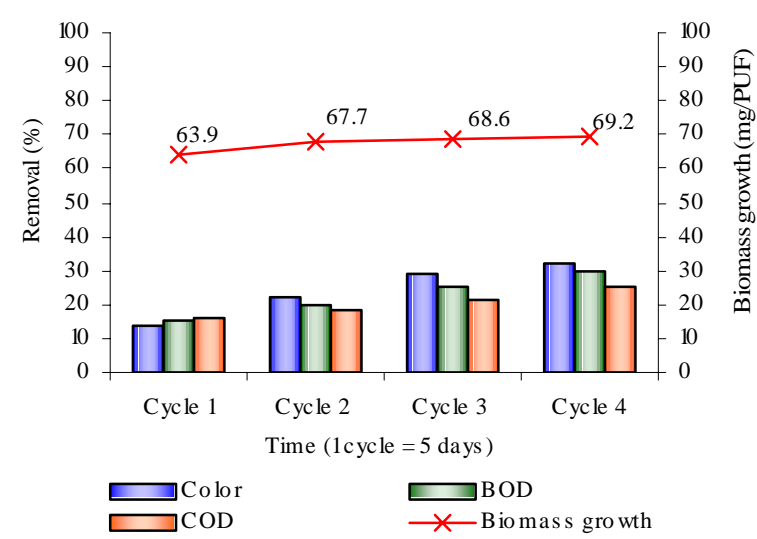

Fig. 3d: Percent removal and respective biomass growth in different cycles using concentrated leachate without glucose (15-day immobilization)

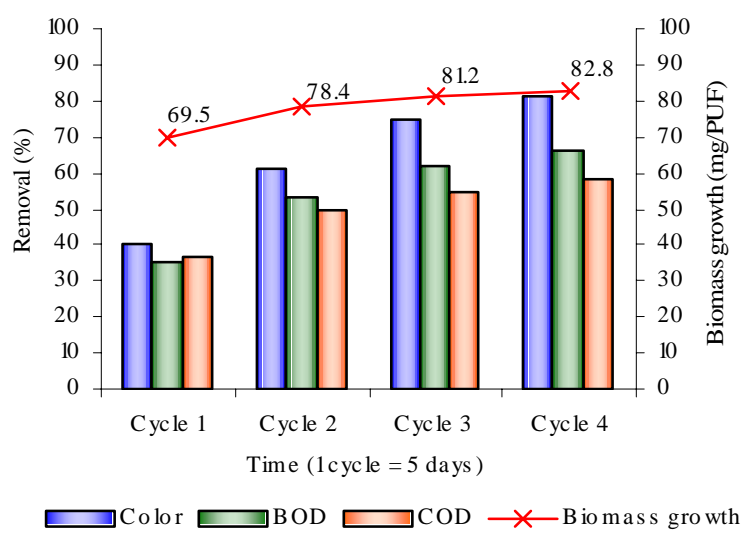

Fig. 3e: Percent removal and respective biomass growth in different cycles using 5-times diluted leachate with glucose (15-day immobilization) 
source such as glucose (Cerniglia, 1997; Knapp et al., 1997; Swamy and Ramsay, 1999) which can be easily used by fungi as it is a simple sugar and helps in producing ligninolytic enzymes (Kirk et al., 1976). Although, the exact role of glucose is not known, it may play a role in decoloration by acting as the substrate for glucose oxidase (Daniel et al., 1994; Machida and Nakanashi, 1984) to generate $\mathrm{H}_{2} \mathrm{O}_{2}$ needed for peroxidase activity or it may produce small organic acids which complex with $\mathrm{Mn}^{3+}$ generated by manganese peroxidase. Relatively high enzyme activities can be obtained only when nitrogen sources are limited (Wu et al., 2005). Thus, co-substrate along with limited nitrogen is very important for biomass growth and decolorization. This is indicated by the results obtained. However, other factors such as the organic loading of leachate in terms of BOD and COD can also affect the removal efficiency. Fungi have higher color removal efficiency (15 \%) in diluted leachate than in concentrated leachate both with and without co-substrate (4 days immobilization).

This indicates that fungi can work better at lower organic loading; however, the fungi is still able to treat concentrated leachate. The recycling of the treated effluent further diluted raw leachate. The advantage of the recycle process is that it can treat the wastewater at very high concentration although extra energy is required for recycling. The color removal was low at the early stage for concentrated leachate because the fungi took time to acclimatize into the new environment and then started degrading the pollutants. After that, the color removal tends to increase sharply. The decolorization slowly increased after the third cycle. Although the leachate is very concentrated, the fungi can still work effectively. This shows that white rot fungi can degrade the organic compounds with time and can be used for treatment of wastewater with high BOD and COD. The initial biomass growth in continuous experiment was higher when the fungi were immobilized on PUF for 15 days rather than 4 days, but the removal efficiency is not high initially and increases significantly after the second cycle. This shows that fungi need time to get acclimatized and perform better once acclimatized to the leachate. Removal efficiency increases after the second cycle and gets better until the last day. The percentage of color removal between cycle 3 and 4 was not much and thus the experiment was stopped after the fourth cycle. Fig. 4 shows the comparison of color, BOD and COD removal in cycle 4 at various conditions. It can be seen that removal for all three parameters is low when no glucose was added as co-substrate, even though the BOD and COD of the leachate is high and this can act as a source of food for fungi. When glucose is added, removal efficiency increases significantly. This clearly indicates that the fungi utilizes readily available glucose as a source of energy for biomass growth and starts degrading the pollutants. Pollutants are removed mostly through degradation by enzymes released by fungi. To some extent, pollutants may be removed by adsorption as well. In general, it can be seen that biomass growth and removal efficiency are related. When biomass growth is higher, removal efficiency is higher also. However, in one set of experiments where fungi was immobilized for 15 days in PDB, which led to higher biomass growth (as compared to 4 days immobilization), still not much removal was observed as glucose was not added as co-substrate. This also strongly supports that fungi required glucose as co-substrate, which is an easily accessible source of energy for fungi. Dilution of leachate reduced organic loading and when such leachate was used, higher removal efficiency (15\% higher color removal) was observed with glucose as cosubstrate and with 4 days initial immobilization.

This shows that organic loading affects the removal efficiency. Dilution of leachate did not significantly increase the removal efficiency when glucose was not added. Fig. 5 shows the ratio of $\mathrm{mg}$ of BOD and COD removed per unit of biomass in continuous experiment in various conditions. Based on the assumption that the glucose was used for the growth of fungi and did not contribute to the BOD and COD of the leachate and biomass growth on PUF is uniform, mg removal of BOD and COD per mg of biomass was calculated. It is interesting to note that the COD removal per unit of biomass is higher than BOD for all cases. It can also be seen that when the leachate is diluted 5 times, the $\mathrm{mg} /$ mg removal of BOD and COD is much less than that of the concentrated leachate. Removal efficiency was slightly better when the fungi was immobilized for 4 days as compared to 15 days immobilization. Although the organic loading is less after dilution, the $\mathrm{mg} / \mathrm{mg}$ removal is much less after dilution as compared to the concentrated leachate. A higher percent of removal was observed when overall removal efficiency was calculated (Fig. 4) for all three parameters after dilution, but the fungi is not utilized to its full potential. Thus, it is better to treat the concentrated leachate with fungi followed by another treatment process. It can be seen that the ratio of the BOD and COD removed to the 
biomass growth in column studies in the four cycles keep increasing with each cycle. This demonstrates that a column experiment may need longer time to reach the stable point. As the $\mathrm{pH}$ of the treated leachate is acidic, lime should be added to adjust the $\mathrm{pH}$ before discharging to the environment.

\section{CONCLUSION}

T. versicolor BCC 8725 used in this study was capable of treating landfill leachate although it was highly contaminated. The removal efficiency was influenced by the organic loading and the co-substrate addition, as well as the degree of immobilization. From this study, the same immobilized fungi on PUF can be reused for at least 4 cycles ( 1 cycle of 5 days each). Dilution of leachate did not significantly increase the removal efficiency when glucose was not added. The maximum color, BOD and COD removal of $63 \%, 52 \%$ and $42 \%$ was achieved in column studies using concentrated leachate with glucose concentration $3 \mathrm{~g} / \mathrm{L}$, whereas $31 \%$, $25 \%$ and 23 $\%$ were obtained when there was no glucose addition (4 days immobilization). About $8 \%$ and $15 \%$ higher color removal was obtained without and with glucose when the leachate was diluted for 5-times $(600 \mathrm{mg} / \mathrm{L}$ of glucose) with 4-day immobilization.

About 1-6 \% higher color removal efficiency was obtained on day 20 when immobilization of fungi on PUF for 15 days was used compared with 4 days immobilization. However, when removal efficiency was calculated in terms of mg removal per mg of biomass, it was found that concentrated leachate with 4 day immobilization and $3 \mathrm{~g} / \mathrm{L}$ glucose as co-substrate gave the highest removal of $0.6 \mathrm{mg}$ COD per $\mathrm{mg}$ of biomass and $0.45 \mathrm{mg}$ BOD per $\mathrm{mg}$ of biomass.

The color removal increased from $40 \%$ to $81 \%$ when glucose was added and leachate was diluted for 5 times with the immobilization of fungi on PUF initially for 15 days.

\section{ACKNOWLEDGEMENTS}

This work was supported by The Joint Graduate School of Energy and Environment (JGSEE), King Mongkut's University of Technology Thonburi (KMUTT), Thailand and their financial support is gratefully acknowledged.

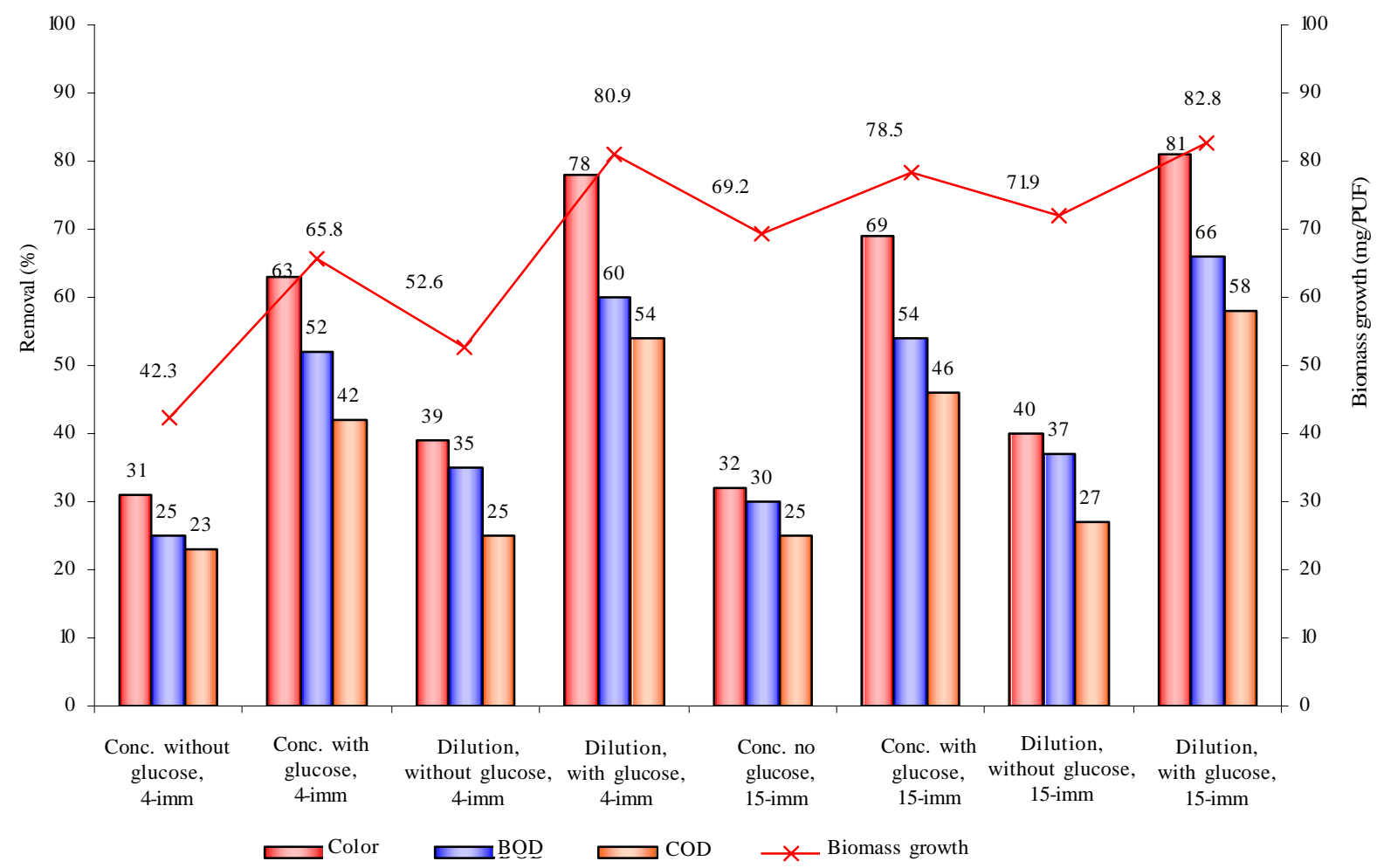

Fig. 4: Comparison of color, BOD and COD removal and biomass growth in cycle 4 at various conditions 


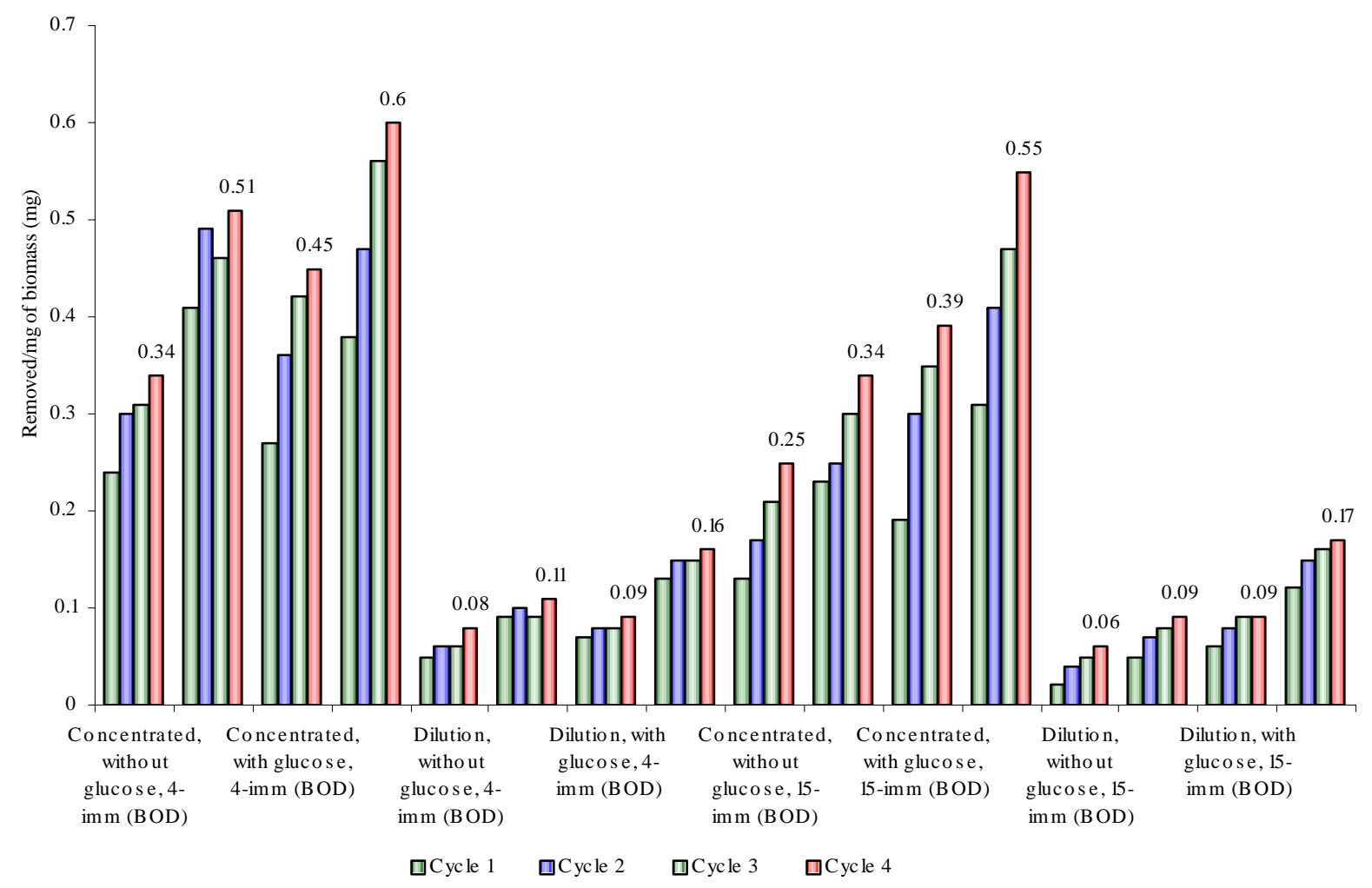

Fig. 5: The ratio of mg of BOD and COD removed per unit of biomass

\section{REFERENCES}

Amaral, P. F. F.; Fernandes, D. L. A.; Tavares, A. P. M.; Xavier, A. B. M. R.; Cammarota, M. C.; Coutinho, J. A. P.; Coelho, M. A. Z., (2004). Decolorization of dyes from textilewastewater by Trametes versicolor. Environ. Tech., 25 (11), 1313-1320 (8 pages).

Benito, G. G.; Miranda, M. P.; Santos, D. R. 1., (1997). Decolorization of wastewater from an alcoholic fermentation process with Trametes versicolor. Bioresour. Tech., 61 (1), 33-37 (5 pages).

Boominathan, K.; Reddy, C. A., (1992). Fungal degradation of lignin: Biotechnological applications. In: Arora D. K.; Elander R. P.; Mukherji K. G. (Eds.), Handbook of applied mycology. Dekker, M., New York, 763-782.

Cerniglia, C. E., (1997). Fungal metabolism of polycyclic aromatic hydrocarbons, past, present and future applications in bioremediation. J. Ind. Microbiol. Biot., 19 (5-6), 324333 (10 pages).

Chiemchaisri, C.; Srisukphun T., (2003). Performance of soil and compost mixture in leachate purification at intermediate cover layer of tropical landfill. In: IWA Conference on Environmental Biotechnology, Advancement on water and wastewater applications in the tropics. December 9-10, Kuala Lumpur, Malaysia.

Daniel, G.; Volc, J.; Kubatova, E., (1994). Pyranose oxidase, a major source of $\mathrm{H}_{2} \mathrm{O}_{2}$ during wood degradation by Phanerochaete chrysosporium, Trametes versicolor and
Oudemansiella mucida. Appl. Environ. Microbiol., 60 (7), 2524-2532 (9 pages).

Erkurt, E. A.; Ünyayar, A.; Kumbur, H., (2007). Decolorization of synthetic dyes by white rot fungi, involving laccase enzyme in the process. Process Biochem., 42 (10), 1429-1435 (7 pages).

Fu, Y.; Viraraghavan, T., (2001). Fungal decolorization of Dye wastewaters: A review. Bioresource Technol., 79 (3), 251-262 (12 pages).

Kandelbauer, A.; Guebitz, G. M., (2005). Bioremediation for the decolorization of textile Dyes - A review. Enviro. Chem., 269-288 (20 pages).

Kim, S. J.; Shoda, M., (1999). Batch decolorization of molasses by suspended and immobilized fungus of geotrichum Candidum. J. Biosci. Bioeng., 88 (5), 586-589 (4 pages).

Kirk, T. K.; Connors, W. J.; Zeikus, J. C., (1976). Requirement for a growth substrate during lignin decomposition by two wood-rotting fungi. Appl. Environ. Icrobiol., 32 (1), 192194 (3 pages).

Kirk, T. K.; Farrell, R. L., (1987). Enzymatic “combustion” and the microbial degradation of lignin. Annu. Rev Microbiol., 41, 465-505 (41 pages).

Knapp, J. S.; Newby, P. S.; Reece, L. P., (1999). Decolorization of dyes by wood-rotting basidiomycete fungi. Enzyme Microb. Technol., 17 (7), 664-668 
(5 pages)

Knapp, J. S.; Zhang, F. M.; Tapley, K. N., (1997). decolourisation of orange II by wood-rotting fungus. J. Chem. Technol. Biot., 69 (3), 289-296 (8 pages).

Lapadatescu, C. ; Feron, G. ; Vergoignan, C.; Djian, A. ; Durand, A. ; Bonnarme, P., (1997). Influence of cell immobilization on the production of Benzaldehyde and Benzyl Alcohol by the white-rot fungi bjerkandera adusta, ischnoderma benzoinum and dichomitus squalens. Appl. Microbiol. Biot., 47 (6), 708-714 (7 pages).

Machida, Y.; Nakanashi, T., (1984). purification and properties of pyranose oxidase from Coriolus versicolor. Agric Biol Chem., 48 (10), 2463-2470 (8 pages).

Martin, C.; Manzanares, A., (1994). A study of decolorization of straw soda pulping effluent by Tramestes versicolor. Bioresource Technol., 47 (3), 209-214 (6 pages).

Mehna, A., Bajpai, P.; Bajpai, P. K., (1995). Studies on decolorization of effluent from a small pulp mill utilizing agri-residues with Trametes versicolor. Enzyme Microb. Technol., 17 (1), 18-22 (5 pages).

Nakamura, Y.; Mtui, G. S.; Tatsuro, S.; Masaaki, K., (1999). Lignin-degrading enzyme production by Bjerkandera adusta immobilized on polyurethane foam. J. Biosci. Bioeng., 88 (1), 41-47 (7 pages).

Nilsson, I.; Moller, A.; Mattiasson, B.; Trubindamayugi, M. S. T.; Welander, U., (2006). Decolorization of synthetic and real textile wastewater by the use of white-rot fungi. Enzyme Microb. Tech., 38 (1-2), 94-100 (7 pages).

Paszczynski, A.; Crawford, R. L., (1995). Potential for bioremediation of xenobiotic compounds by the white rot fungus Phanerochaete chrysosporium. Biotech. Progr., 11 (4), 368-379 (12 pages).
Pointing, S. B., (2001). Feasibility of bioremediation by white rot fungi. Appl. Microbiol. Biotech., 57 (7), 20-33 (14 pages).

PCD, (2005). Pollution Control Department, State of Thailand's Pollution, http://www.pcd.go.th/public/ report45.pdf

Reddy, A., (1995). The potential for white-rot fungi in the treatment of pollutants. Curr. Opin. Biotech., 6 (3), 320328 (9 pages).

Sathiya Moorthi, P.; Periyar Selvam, S.; Sasikalaveni, A.; Murugesan, K.; Kalaichelvan, P. T., (2007). Decolorization of textile dyes and their effluents using white rot fungi. Af. J. Biotech., 6 (4), 424-429 (6 pages).

Selvam, K.; Swaminathan, K.; Myung, H. S.; Keon-Sang, Ch., (2002). Biological treatment of a pulp and paper industry effluent by Fomes lividus and Trametes versicolor. World J. Microbiol. Biotech., 18 (6), 523-526 (4 pages).

Shah, V.; Nerud, F., (2002). Lignin degrading system of whiterot fungi and its exploitation for dye decolorization. Can. J. Microbiol., 48 (10), 857-870 (14 pages).

SMEW, (1998). Standard Methods for the Examination of Water, $20^{\text {th. }}$ Ed. APHA, AWWA and WEF, Washington, DC.

Swamy, J.; Ramsay, J. A., (1999). Effect of $\mathrm{Mn}^{2+}$ and ammonium concentration on laccase and manganese peroxidase production and amaranth decoloration by trametes versicolor. Appl. Microbiol. Biotech., 51 (3), 391-396 (6 pages).

Wu, J.; Xiao, Ya-Zhong,; Yu, Han-Qing, (2005). Degradation of lignin in pulp mill wastewaters by white rot fungi on biofilm. Bioresour. Tech., 96 (12), 1357-1363 (7 pages).

USEPA, (2007). Summary of the EPA municipal solid waste program.U.S. Environmental Protection Agency. http:// www.epa.gov/reg3wcmd/solidwaste summary.htm.

\section{AUTHOR (S) BIOSKETCHES}

Saetang, J., Ph.D. candidate, School of Biochemical Engineering and Technology Program, Sirindhorn International Institute of Technology (SIIT), Thammasat University, P.O. Box 22, Pathumthani 12121, Thailand. Email: sjenjira@yahoo.com

Babel, S., Associate professor, School of Biochemical Engineering and Technology Program, Sirindhorn International Institute of Technology (SIIT), Thammasat University, P.O. Box 22, Pathumthani 12121, Thailand. Email: sandhya@siit.tu.ac.th

This article should be referenced as follows:

Saetang, J.; Babel, S., (2009). Effect of leachate loading rate and incubation period on the treatment efficiency by T. versicolor immobilized on foam cubes . Int. J. Environ. Sci. Tech., 6 (3), 457-466. 